\title{
Emerging Market Firms' Response to U.S. Economic Recession and the Subsequent Period's Performance
}

TeWhan Hahn, PhD

Auburn University at Montgomery, Montgomery, Alabama, United States

(iD) https://orcid.org/o0oo-0002-8946-3102

Ravi Chinta, $\mathrm{PhD}$

Nova Southeastern University, Fort Lauderdale, Florida, United States

(iD https://orcid.org/oooo-0002-8762-8508

Contact: thahn@aum.edu

\begin{abstract}
We investigated the changes in behaviors of firms in emerging markets in response to the U.S. economic recession and the impact of those changes in strategic behaviors on subsequent periods' operating performances. Specifically, we adopted an event-study methodology, using a sample of emerging market firms, to investigate the nature of the effects of the U.S. economic recession on firms in emerging markets. Based on 5,887 firms in nine emerging countries, our results show that firms in emerging markets exhibit changes in strategy variables, and those changes have a significant effect on the subsequent periods' operating performance. In addition, we found that the impact of changes in strategy variables on the subsequent periods' operating performance is stronger among more resource-unconstrained firms than among more resource-constrained firms. We ascribe this latter finding to the lack of slack resources that are necessary to make changes in strategy variables during the aftermath of the global economic recession for more resourceconstrained firms.
\end{abstract}

Keywords: global impact of events in the United States; longitudinal firm performance; determinants of firm performance; resource constraints

Date Submitted: June 1, 2021 | Date Published: November 3, 2021

\section{Recommended Citation}

Hahn, T., \& Chinta, R. (2021). Emerging market firms' response to U.S. economic recession and the subsequent period's performance. International Journal of Applied Management and Technology, 20, 88-105.

https://doi.org/10.5590/IJAMT.2021.20.1.05

\section{Introduction}

A firm's strategy is best understood by examining the behaviors and actions of the firm's operating in the broader environmental context in which the firm is embedded. Both external and internal environments are analyzed in making resource allocation decisions, where deployed resources include money, time, people, technological knowledge, and social capital. According to Dess et al. (2019), the basis of strategy formulation 
is that "one of the primary attributes of strategic management is directing the organizational behaviors and actions in response to external forces" (p. 7). For instance, economic recessions coerce firms to change their strategies to ensure survival, and such changes in a firm's behaviors and actions consequently impact the firm's performance in the subsequent years. Because recessions adversely impact the availability of credit and demand for products and services, it is to be expected that external shocks, such as extreme recessions, can inhibit firms from securing and allocating resources. Extant literature on organizational slack shows that the impact of similar strategies could be widely different between more constrained firms and less constrained firms in terms of available resources as a buffer. In other words, firms with more slack may experience different effects on a firm's performance from their efforts of securing and allocating their resources than would their counterparts with less slack.

We examined 2008-2010 as a recessionary period representing an external shock that provided a quasiexperimental environment for this research. That is, given a sudden and adverse discontinuity in the external environment that cut across all firms, did firms with different levels of organizational slack respond differently and, consequently, experience different levels of the firm's performance? Additionally, by focusing on firms in emerging markets, our study investigated whether economic recessions in the United States have a global impact beyond the domestic boundaries.

\section{Literature Review}

Our research scope emerged from the intertwining of two strands of research: (1) the research on external shocks and their impact on firm behaviors, and (2) the research on organizational slack, which is a firm-level variable that varies across firms. We briefly explore these strands of research in this paper.

\section{External Shocks}

A firm's strategy is highly context specific, and the environment in which the firm is embedded has a significant impact on its strategy and the consequent performance of the firm. From the viewpoint of contingency theory, the environment is the factor that has a direct influence on strategy and performance (Lawrence \& Lorsch, 1967; Keller, 1994; Thompson, 2017). This idea of "environmental determinism" was called the Bain-Mason (industrial organization) model that offered strategic management a strong rationale for doing external analysis before formulating firm strategies, and that firm strategy mediates the relationship between the environment and the firm's performance (Porter, 1981; Venkatraman, 1989). Discontinuities are critical moments for incumbent firms because they challenge firms to survive and adapt (Cozzolino \& Rothaermel, 2018). Especially when unexpected discontinuities in the external environment occur, significantly different coping strategies are needed to deal with external shocks. Thus, one can expect changes in strategic behaviors leading to consequent firm performance outcomes when external shocks do occur. As sudden discontinuities often unexpectedly occur, at least uncertain in their timing, firms oftentimes resort to developing coping mechanisms (Geroski \& Gregg, 1997), such as disaster planning or building organizational slack that can serve as buffers (Lado et al., 1992; Patel \& Cooper, 2014). Economic recessions adversely lead to forward-looking growth initiatives at the firm level (González-Pernía et al., 2018; Rusu \& Roman, 2017; Le Breton-Miller \& Miller, 2015). Previous studies have shown that economic recessions can severely affect the performance of individual firms, industries, and entire economic sectors (Domowitz et al., 1988; Gabisch \& Lorenz, 1987; Zarnowitz, 1985). Our study focused on changes in the firms' behaviors as a result of external shocks.

\section{Organizational Slack}

George (2005) defines slack resources as "potentially utilizable resources that can be diverted or redeployed for the achievement of organizational goals" (p. 661). Studies proposed both positive and negative effects of 
slack (Vanacker et al., 2017); organizational slack buffers the firm from rapid changes in its external environment (Bansal, 2003), enhances the firm's capacity to adjust to shifts in consumer demand (Pfeffer \& Salancik, 1978), and leads to operational inefficiency (Singh, 1986; Latham \& Braun, 2008). Some resourcebased view theorists argue that key organizational resources that are not easily replicated by competitors will result in the firm's success (Wernerfelt, 1984; 1995), while others suggest the allocation processes used by the firm directly impact the firm's performance (Teece, 2007; Wu, 2007). The logic simply is that excess (internal) cash resources-which are usually viewed as easy to redeploy-benefit the firm's performance, especially when firms operate in economic contexts that have weak credit. Our current study splits the sample into either more financially constrained firms or less financially constrained firms and examines whether a change in securing and allocating resources (i.e., change in strategy) has a differential effect on the firm's performance between more financially constrained firms and less financially constrained firms.

\section{Financial Constraints}

The effect of financial constraints on fixed investment and employment decisions is well documented and nontrivial. Problems of information asymmetry among management and financial institutions, transaction costs, and agency conflicts may limit the firm's ability to access capital markets, making them financially constrained. Access to financial capital remains a major determinant for allocation of resources to growth initiatives at the firm level (Beck \& Demirgüç-Kunt, 2008). Financially constrained firms face higher costs of borrowing from the capital markets as compared with the costs of internally generated funds, resulting in subsequent negative effects on real activity for these firms (Fazzari et al., 1988; Caggese et al., 2018). This wedge $^{1}$ between the internal and external costs of funds can increase during periods of credit crisis, which brings sharp reductions in lending by financial institutions. This is especially true in emerging markets and markets where firms face poorer access to financial markets. ${ }^{2}$ Supporting this argument, Campello et al. (2010) found that the credit crisis exacerbated the effect of financial frictions on firm behavior. In a survey of 1,050 Chief Financial Officers (CFOs) across the U.S., Europe, and Asia, Campello et al. (2010) showed that, during the credit crisis of 2008, financially constrained firms experienced higher costs of financing and were more likely to cut capital spending, exhaust internal cash reserves, sell assets to support the operational needs, and cancel or postpone planned investments as compared to financially unconstrained firms.

The 2008 global crisis environment allowed the U.S. to contrast the effects of directional changes in strategic decisions on the operating performance for firms that are more financially constrained with those that are less financially constrained.

\section{Firm Performance}

Firm performance, an outcome measure of a firm's behavior and actions, has been a subject of intense study in the literature (O'Reilly \& Pfeffer, 2000; Hess \& Kazanjian, 2006; Thoenig \& Waldman, 2007; Gottfredson \& Schaubert, 2008; Simons, 2008; Tappin \& Cave, 2008; Spear, 2009). Among the many theories of a firm's performance explaining its determinants are the Bain-Mason industrial organization view (Porter, 1981), resource-based view (Wernerfelt, 1984, 1995), and dynamic capabilities (Peteraf \& Barney, 2003; EasterbySmith et al., 2009; Teece, 2007; Chinta \& Culpan, 2014). In the literature on the resource-based view and dynamic capabilities, many different factors are identified as impacting a firm's performance.

\footnotetext{
${ }^{1}$ Fazzari et al. (1988) define financial constraints in terms of a wedge between the firm's cost of internal capital and its cost of external capital.

${ }^{2}$ Mizen and Tsoukas (2012) also note that information asymmetry is considerably high in Asian countries due to lower reporting requirements.
} 
However, the reality is such that a firm's performance is fraught with significant variance. Variance can come from the endogenous strategies of firms based on a "resource-based view" of the firm and from exogenous forces that impinge upon the firm with a significant interaction between endogenous and exogenous factors. Our study aimed to explain empirically how an exogenous event affects a firm's behavior and performance. We have chosen to study the periods before and after the exogenous event and make inferences about the effects of the event on the firm's behavior and performance.

\section{Research Model and Hypothesis Development}

The environmental determinism strand of research suggests that external forces impact and shape firm strategies, and organizational slack theories suggest that firms with little or no financial constraints can withstand the adverse impacts of negative external forces that are recessionary in nature. Intertwining these three strands of extant research, we present our research model.

Stemming from the Research Model above, the following two hypotheses are empirically tested in this study.

Hypothesis 1: When faced with external shocks, all firms change their strategic behaviors and experience changes in the firm's performance. That is, postrecession performance for all firms is impacted by changes in strategic behaviors induced by the external shocks.

Hypothesis 2: When faced with external shocks, the impact of some strategic behaviors on the firm's performance would be different for firms with negative ROE/ROA compared with firms with positive ROE/ROA before the U.S. recession.

Following prior studies examining the impact of the global crisis on international markets (Bliss et al., 2015; González, 2016; Lins et al., 2013; Hahn et al., 2017), we used 2007 as the start year of the crisis and assigned 2007-2008 as the crisis period to capture the impact of the crisis. We determined 2001-2006 as the precrisis period, 2007-2008 as the crisis period, and 2009 and 2010 as the postcrisis period.

\section{Sample, Variables, and Measures}

\section{Sample}

Our sample was composed of 5,887 firms from nine emerging stock markets: Brazil, China, Greece, India, Malaysia, Portugal, South Africa, Sri Lanka, and Thailand. India had the greatest number of firms with 2,547, and China followed with 1,446 (Table 1).

Table 1. List of Countries

\begin{tabular}{lc}
\hline Country & No. of Firms \\
\hline Brazil & 200 \\
China & 1,446 \\
Greece & 196 \\
India & 2,547 \\
Malaysia & 725 \\
Portugal & 37 \\
South Africa & 209 \\
Sri Lanka & 157 \\
Thailand & 370 \\
Total & $\mathbf{5 , 8 8 7}$ \\
\hline
\end{tabular}


The sample covered 2001-2010. Accounting variables were drawn from Compustat Global files. We followed Frazzini and Pedersen (2014) and identified each firm to its country based on the location of the primary exchange. We excluded financial firms (SIC code 6000-6999) as they carry debt and cash for regulatory reasons. We also required that firms have positive assets, positive sales, and positive book equity. Finally, we required that the firms appear in the sample for at least 1 year during 2001-2007 and at least 1 year during 2008-2010. The last requirement ensured that the firm existed before, during, and after the recent great recession. Since R\&D expenses (Compustat Global Item $x r d$ ) were missing in two-thirds of the firms' years, we set the missing values to zero to avoid losing many observations. Following standard practice with international samples, we winsorized continuous variables at the top and bottom $1 \%$ within each country to ensure that the results were not driven by data errors or illiquid stocks (Dittmar et al., 2003; Palkar, 2017).

\section{Strategy Variables and Firm Performance Measures}

We accounted for several strategy variables that are known to affect firm performance, such as sales, equity capital, the ratio of working capital to sales, the ratio of capital expenditures to sales, leverage, the ratio of $R \& D$ expenditures to sales, and the ratio of cash to total assets. Table 2 describes the variables along with their abbreviated names used in the empirical analysis. Column 2 of Table 2 presents relevant prior studies that used changes in these variables over time as measures of strategic behaviors that impact a firm's performance. For the sake of brevity, only a few representative prior studies are presented, although there is a long history of research that established the relevance of these variables to explain firm strategies and performance.

Table 2. Research Variables Names and Descriptions

\begin{tabular}{|c|c|}
\hline Variable Name $\left(^{*}\right)$ & $\begin{array}{l}\text { Representative prior research studies that establish a change in this variable as a strategic } \\
\text { behavior with impact on a firm's performance }\end{array}$ \\
\hline Sales (sale) & $\begin{array}{l}\text { While many studies use sales as a control variable, change in sales (contraction or expansion) can be } \\
\text { viewed as a strategic behavior (Evans, 1987; Hong et al., 2000; Uyar, 2009). Relative changes over } \\
\text { time are used as measures of strategic behavior in multivariate analyses of a firm's performance. }\end{array}$ \\
\hline Equity (seq) & $\begin{array}{l}\text { Changes in capital structure (debt versus equity) of the business impact a firm's performance } \\
\text { (Dewatripont \& Tirole, 1994; Dalton et al., 2003; Margaritis \& Psillaki, 2010; Almazari, 2012; } \\
\text { Chang et al., 2012). Over time, the shift has been toward ownership concentration for corporate } \\
\text { governance rather than absolute equity (Mandacı \& Gumus, 2010). }\end{array}$ \\
\hline $\begin{array}{l}\text { Ratio of Wcap/Sale } \\
\text { (rect-ap)/sale) }\end{array}$ & $\begin{array}{l}\text { As firms embrace more efficient working management methods, prior empirical research } \\
\text { documents the effect of changes in working capital on a firm's performance that also extends to } \\
\text { international contexts (Aktas et al., 2015; Enqvist et al., 2014; Kieschnick et al., 2013; Ding et al., } \\
\text { 2013; Gill et al., 2010; Juan García-Teruel \& Martinez-Solano, 2007; Deloof, 2003). }\end{array}$ \\
\hline $\begin{array}{l}\text { Ratio of Capital } \\
\text { Expenditure/Sale } \\
\text { (capx/sale) }\end{array}$ & $\begin{array}{l}\text { As the knowledge economy transforms a firm's assets to become more intangible, changes in } \\
\text { investment intensity and a firm's performance have been widely studied in various empirical } \\
\text { contexts. Examples include Cusumano, 2010; Cooper et al., 2008; Fama \& French, 2006; } \\
\text { Eisenmann, 2006; Lamont, 1997; Severn \& Laurence, 1974. }\end{array}$ \\
\hline $\begin{array}{l}\text { Ratio of } \\
\text { Leverage/Assets } \\
(d l c+d l t t) / a t)\end{array}$ & $\begin{array}{l}\text { Like the parallel stream of research on equity and capital structure noted, considerable research } \\
\text { exists on the effect of changes in debt leverage on a firm's performance. Examples include Abel, } \\
\text { 2018; Cole et al., 2015; Joliet \& Muller, 2013; and Penman et al., 2007. }\end{array}$ \\
\hline Ratio of R\&D & The impact of changes in R\&D expenses (more or less innovation) over time on a firm's \\
\hline $\begin{array}{l}\text { Expenditure/Assets } \\
\text { (xrd/sale) }\end{array}$ & $\begin{array}{l}\text { performance is studied extensively and continues in its intensity as the nature of innovation is } \\
\text { shifting toward collaborative research. Examples include Bogers et al., 2016; Chinta \& Culpan, } \\
\text { 2014; House et al., 1994; Denicolai et al., 2014; Baden-Fuller \& Haefliger, 2013; Hauser et al., } \\
\text { 2006; Grabowski et al., 2002; Morbey et al., 1990; and Nakao, 1993. }\end{array}$ \\
\hline $\begin{array}{l}\text { Ratio of Cash/Assets } \\
\text { (che/at) }\end{array}$ & $\begin{array}{l}\text { Prior studies, such as Kim et al. (1998), Opler et al. (1999), and Mikkelson \& Partch (2003), } \\
\text { provide evidence that cash holdings enhance a firm's value. More recently, Chang et al. (2017) } \\
\text { showed that cash is a valuable source of investment funding during periods of financial crisis, } \\
\text { especially for constrained firms. }\end{array}$ \\
\hline
\end{tabular}

*All variables are from Compustat Global. The terms in italics refer to the Compustat Global variable names. 
Our dependent variable was a firm's performance because we were attempting to investigate the impact of strategic behaviors on a firm's performance. A firm's performance can be measured using market-based performance metrics and operational performance metrics. We employed accounting-based measures of a firm's performance instead of market-based measures, as suggested by Wintoki et al. (2012). They argued that the relation between a firm's strategic behaviors and market-based measures of a firm's performance, such as stock returns or Tobin's $Q$, may be problematic because market-based measures proxy for growth opportunities, and growth opportunities are a cause, rather than a consequence, of a firm's strategic behaviors.

The primary operating performance measure (Carpenter, 2002) we used was return on assets (ROA), defined as net income-income before extraordinary items (Compustat Global Item $i b$ ) minus preferred dividends (Compustat Global Item $d v p$ ) plus deferred income taxes (Compustat Global Item $t x d i$ ) divided by total assets (Compustat Global Item at)-based on İmrohoroğlu and Tüzel (2014). In addition, we also used return on equity (ROE) to ensure that our results were robust to alternative measures of performance. ROE is defined as income before extraordinary items (Compustat Global Item $i b$ ) divided by shareholders' equity (Compustat Global Item seq).

Table 3 reports the descriptive statistics for the key firm-level variables for 2009 and 2010. The average (median) firm size measured in sales in 2009 is $\$ 375.97$ mil (\$70.32 mil) for the sample of 5,887 firms from the nine emerging markets. Between the two firm performance variables, ROE exhibits the higher variation as seen in standard deviation in both 2009 and 2010. To avoid sample selection problems, we did not require a balanced panel. That is, the number of firms differed each year, and we used all available observations in the regression analysis.

Table 3. Descriptive Statistics

\begin{tabular}{lrrrr}
\hline Variable Name & N & Mean & Median & Std Dev \\
\hline Panel A: 2OO9 & & & & \\
ROA & 5,875 & 0.0912 & 0.0863 & 0.0874 \\
ROE & 5,887 & 0.0656 & 0.0769 & 0.2176 \\
Capx/Sale & 5,887 & 0.1066 & 0.0415 & 0.2047 \\
Cash/Assets & 5,887 & 0.1265 & 0.0783 & 0.1393 \\
Lev/Equity & 5,887 & 0.8764 & 0.4844 & 1.2810 \\
Sale (\$mil) & 5,887 & 375.97 & 70.32 & 1115.11 \\
Equity (\$mil) & 5,887 & 203.07 & 45.74 & 593.70 \\
WCap/Sale & 5,887 & 0.1862 & 0.0810 & 0.9346 \\
R\&D/Sale & 5,887 & 0.0028 & 0.0000 & 0.0161 \\
Panel B: 2O1O & & & & \\
ROA & 5,877 & 0.0909 & 0.0853 & 0.0862 \\
ROE & 5,887 & 0.0661 & 0.0828 & 0.2294 \\
Capx/Sale & 5,887 & 0.1064 & 0.0442 & 0.2019 \\
Cash/Assets & 5,887 & 0.1255 & 0.0769 & 0.1382 \\
Lev/Equity & 5,887 & 0.8770 & 0.4722 & 1.2671 \\
Sale (\$mil) & 5,887 & 442.25 & 84.29 & 1239.96 \\
Equity (\$mil) & 5,887 & 236.97 & 54.58 & 667.82 \\
WCap/Sale & 5,887 & 0.1893 & 0.0785 & 0.9856 \\
R\&D/Sale & 5,887 & 0.0026 & 0.0000 & 0.0156 \\
\hline
\end{tabular}




\section{Empirical Results}

\section{Analytical Methodology}

To investigate the relation between changes in strategic behaviors and operating firm performance, we estimated our baseline model (1) to test Hypothesis 1 as follows:

Operating Performanceit $+1=\alpha 0+\alpha 1^{*} \Delta$ Saleit $+\alpha 2^{*} \Delta$ Equityit $+\alpha 3^{*} \Delta$ WCap/Saleit $+\alpha 4^{*} \Delta$ Capx $/$ Saleit + $\alpha 5^{*} \Delta$ Lev/Assetsit $+\alpha 6^{*} \Delta \mathrm{R} \& \mathrm{D} /$ Saleit $+\alpha 7^{*} \Delta$ Cash/Assetsit + eit

where Operating Performance is the firm's operating performance measured by ROA or ROE in (postcrisis) 2009 and 2010. The strategy variables used in the study were sales (Sale), equity capital (Equity), working capital scaled by sales (WCap/Sale), capital expenditure scaled by sales (Capx/Sale), leverage scaled by total assets (Lev/Assets), research and expenditure scaled by sales (R\&D/Sale), and cash scaled by total assets (Cash/Assets). $\Delta$ refers to a directional dummy variable that has value of 1 if the change in the strategy variable between the precrisis period of 2001-2006 and the crisis period of 2007-2008 was positive, and o otherwise. To control country effect on a firm's performance, a country dummy was used for each country in the sample.

To test Hypothesis 2, we estimated the separate regression models on negative ROA/ROE sample and positive ROA/ROE sample. It is likely that firms experiencing negative ROA/ROE in the U.S. prerecession period would respond differently in strategies faced with external shocks, such as recession, maybe because they have much fewer resources to use to make changes in strategies than firms experiencing positive ROA/ROE in the U.S. prerecession period.

\section{Correlations}

Table 4 reports the bivariate correlations between dependent variables (firm performance measures, ROA, and ROE) and independent variables (directional change in strategies). The results show that five independent variables are consistently and statistically significantly correlated with dependent variables. Increases in sales, equity capital, cash, and R\&D expenditure during the crisis period are positively related to the firm's performance in the subsequent years, and an increase in debt financing during the crisis period is negatively related to the firm's performance in the subsequent years.

Table 4. Correlation Matrix

\begin{tabular}{lcccc}
\hline \multirow{2}{*}{ Variable } & \multicolumn{2}{c}{$\mathbf{2 0 0 9}$} & \multicolumn{2}{c}{$\mathbf{2 0 1 0}$} \\
\cline { 2 - 5 }$\Delta$ SALE & ROA & ROE & ROA & ROE \\
\cline { 2 - 5 }$\Delta$ Equity & 0.2979 & 0.1758 & 0.2601 & 0.1508 \\
$\Delta$ WCap/SALE & 0.2376 & 0.1881 & 0.1962 & 0.1266 \\
$\Delta$ Capx/SALE & 0.0354 & 0.0176 & 0.0261 & 0.0104 \\
$\Delta$ Lev/Equity & 0.0659 & 0.0471 & 0.0370 & -0.0070 \\
$\Delta$ R\&D/SALE & -0.0415 & -0.0770 & -0.0397 & -0.0768 \\
$\Delta$ Cash/Assets & 0.0856 & 0.0433 & 0.0613 & 0.0029 \\
\hline
\end{tabular}




\section{Full Sample Results}

Table 5 reports the firm's performance regression results using the full sample. The results from the multivariate analysis are consistent with those from bivariate correlational analysis in the correlation matrix in Table 4. The $t$-statistics in all regressions are computed from the heteroscedasticity-consistent standard errors of White (1980).

Regardless of the firm's performance measures used (ROA or ROE) and year (2009 or 2010), increases in sales, equity capital, R\&D, and cash during the great recession significantly and positively affected the firm's performance in the subsequent years (except R\&D on ROE in 2010), and increase in debt financing (leverage) significantly and negatively affected a firm's performance in the subsequent years. An increase in working capital showed a positive effect on a firm's performance, but it is statistically significant for ROA of 2009 only. An increase in capital expenditures did not show a consistent effect on a firm's performance, but when it had a statistically significant effect on a firm's performance, it showed a positive effect (ROA of 2009).

Overall, the results of Table 5 render support to Hypothesis 1 that the U.S. postrecession operating performance for all firms in emerging markets was affected by changes in strategic behaviors induced by macroeconomic shocks.

Table 5. Regression Results of Full Sample

\begin{tabular}{|c|c|c|c|c|}
\hline \multirow[b]{2}{*}{ Variable } & \multicolumn{2}{|c|}{2009} & \multicolumn{2}{|c|}{2010} \\
\hline & ROA & ROE & ROA & ROE \\
\hline Intercept & $0.0275^{* * *}$ & $-0.0923^{* * *}$ & $0.0522^{* * *}$ & -0.0223 \\
\hline t-value & $4 \cdot 71$ & -4.56 & 8.53 & -1.01 \\
\hline$\triangle \mathrm{SALE}$ & $0.0622^{* * * *}$ & $0.0763^{* * *}$ & $0.0543^{* * *}$ & $0.0728 * * *$ \\
\hline t-value & 18.76 & 7.80 & $15 \cdot 71$ & $7 \cdot 33$ \\
\hline$\Delta$ Equity & $0.0282^{* * *}$ & $0.0703^{* * *}$ & $0.0205^{* * *}$ & $0.0364^{* * *}$ \\
\hline t-value & 8.63 & 6.04 & 6.11 & 3.50 \\
\hline$\Delta$ WCap/SALE & $0.0041^{*}$ & 0.0059 & 0.0016 & 0.0033 \\
\hline t-value & 1.93 & 1.06 & 0.75 & 0.55 \\
\hline$\Delta$ Capx/SALE & $0.0038^{*}$ & 0.0073 & 0.0004 & -0.0091 \\
\hline t-value & 1.79 & $1.4 O$ & 0.22 & -1.56 \\
\hline$\Delta$ Lev/Equity & $-0.0092^{* * *}$ & $-0.0315^{* * *}$ & $-0.0091^{* * *}$ & $-0.0305^{* * *}$ \\
\hline t-value & -4.25 & $-5 \cdot 72$ & -4.19 & -5.16 \\
\hline$\triangle \mathrm{R} \& \mathrm{D} / \mathrm{SALE}$ & $0.0138^{* * *}$ & $0.0187^{* *}$ & $0.0100^{* * *}$ & 0.0062 \\
\hline t-value & 4.12 & 2.16 & 3.00 & 0.67 \\
\hline$\Delta$ Cash/Assets & $0.0090^{* * *}$ & $0.0234^{* * *}$ & $0.0056^{* * *}$ & $0.0160^{* * *}$ \\
\hline t-value & 4.21 & 4.18 & 2.60 & 2.81 \\
\hline Adj R ${ }^{2}$ & 0.1528 & 0.0680 & 0.1250 & 0.0594 \\
\hline Obs & 5,875 & 5,887 & 5,877 & 5,887 \\
\hline Country Dummies & Yes & Yes & Yes & Yes \\
\hline
\end{tabular}

Notes. The $t$-value is $t$-statistic computed from the heteroscedasticity-consistent standard errors. $*, * *, * *$ indicate significance at the $10 \%, 5 \%$, and $1 \%$ levels, respectively. 


\section{Regression Results of the Negative ROE and ROA Sample}

While results for the full sample in Table 5 captured the variation across all the firms, we explored the variation for the subsamples (i.e., the negative ROE/ROA subsample, i.e., financially constrained firms) and the positive ROE/ROA subsample (i.e., financially unconstrained firms) to see whether and how the important set of strategy variables are different between the two subsamples.

Table 6 shows results for the negative ROE/ROA subsample. In comparison to the results of the full sample in Table 5, both signs and statistical significance of coefficients of independent variables were starkly different: First, there was no independent variable that showed statistical significance in a consistent manner. This may mean that the firms experiencing negative ROE/ROA before the recession either did not make much change in their strategies during the recession or the firm's performance after the recession was not big enough in response to changes in strategies. Perhaps firms experiencing negative ROE/ROA were constrained in resources to use to make changes in strategies unlike the firms experiencing positive ROE/ROA, which supposedly would have more resources to deploy to make changes in strategies in response to recession. Second, only increases in leverage and capital expenditure during the recession had a consistent negative effect on the firm's performance, although increase in leverage was statistically significant for ROE only and increase in capital expenditure was not statistically significant at all. All other independent variables, increases in sales, equity capital, working capital, R\&D, and cash, showed different signs and statistical significance of coefficients.

Table 6. Regression Results of Sample Experiencing Negative ROA and ROE

\begin{tabular}{|c|c|c|c|c|}
\hline \multirow[b]{2}{*}{ Variable } & \multicolumn{2}{|c|}{2009} & \multicolumn{2}{|c|}{2010} \\
\hline & ROA & ROE & ROA & ROE \\
\hline Intercept & $-0.0805^{* * *}$ & $-0.3400^{* * *}$ & $-0.0640^{* * *}$ & $-0.1972^{* * *}$ \\
\hline t-value & -7.86 & -5.56 & -5.07 & -2.62 \\
\hline$\triangle$ SALE & 0.0009 & -0.0215 & -0.0001 & 0.0177 \\
\hline t-value & 0.21 & -1.03 & -0.02 & 0.75 \\
\hline$\Delta$ Equity & $0.0109^{* *}$ & $0.0885^{* * *}$ & -0.0056 & -0.0238 \\
\hline t-value & 2.32 & 3.72 & -1.18 & -0.97 \\
\hline$\Delta$ WCap/SALE & -0.0002 & -0.0087 & 0.0006 & 0.0084 \\
\hline t-value & -0.06 & -0.43 & 0.13 & 0.35 \\
\hline$\Delta \mathrm{Capx} / \mathrm{SALE}$ & -0.0039 & -0.0080 & -0.0069 & -0.0342 \\
\hline t-value & -0.88 & -0.42 & -1.45 & -1.45 \\
\hline$\Delta$ Lev/Equity & -0.0021 & $-0.0795^{* * *}$ & -0.0073 & $-0.0628^{* * *}$ \\
\hline t-value & -0.45 & -4.06 & -1.49 & -2.77 \\
\hline$\triangle \mathrm{R} \& \mathrm{D} / \mathrm{SALE}$ & $-0.0213^{* *}$ & -0.0094 & $-0.0156^{*}$ & 0.0102 \\
\hline t-value & -2.36 & -0.34 & -1.83 & 0.32 \\
\hline$\Delta$ Cash/Assets & 0.0049 & 0.0313 & -0.0016 & 0.0330 \\
\hline t-value & 1.15 & 1.54 & -0.34 & 1.42 \\
\hline Adj $R^{2}$ & 0.1091 & 0.0863 & 0.1179 & 0.0609 \\
\hline Obs & 603 & 1,033 & 598 & 1,033 \\
\hline Country Dummies & Yes & Yes & Yes & Yes \\
\hline
\end{tabular}

Notes. The $t$-value is $t$-statistic computed from the heteroscedasticity-consistent standard errors. $*, * *, * * *$ indicate significance at the $10 \%, 5 \%$, and $1 \%$ levels, respectively. 


\section{Regression Results of the Positive ROE and ROI Sample}

Results on the positive ROE/ROI subsample are given in Table 7. The most striking finding was that the signs of four independent variables exhibited the same signs as those in the full sample results: Increases in sales, working capital, R\&D, and cash positively affected a firm's performance in the U.S. postrecession years although the statistical significance of working capital and cash was limited. In contrast, increases in equity capital, capital expenditures, and leverage affected a firm's performance in an inconsistent manner: Increase in equity capital during recession affected ROA positively but ROE negatively in the U.S. postrecession years. Increase in capital expenditure had a positive impact on a firm's performance, except for ROE in 2010.

Increase in leverage had a statistically significant negative impact on a firm's performance, except for ROE in 2010.

Table 7. Regression Results of Sample Experiencing Positive ROA and ROE

\begin{tabular}{|c|c|c|c|c|}
\hline \multirow{2}{*}{ Variable } & \multicolumn{2}{|c|}{2009} & \multicolumn{2}{|c|}{2010} \\
\hline & ROA & ROE & ROA & ROE \\
\hline Intercept & $0.0756^{* * *}$ & $0.0975^{* * *}$ & $0.0912^{* * *}$ & $0.1228 * * *$ \\
\hline t-value & 15.01 & 11.95 & 17.10 & 13.71 \\
\hline$\triangle \mathrm{SALE}$ & $0.0445^{* * *}$ & $0.0444^{* * *}$ & $0.0389^{* * *}$ & $0.0376^{* * *}$ \\
\hline t-value & 15.03 & $7 \cdot 31$ & 12.23 & 6.31 \\
\hline$\Delta$ Equity & $0.0150^{* * *}$ & $-0.0140^{* *}$ & $0.0106^{* * *}$ & $-0.0134^{* *}$ \\
\hline t-value & 5.21 & -2.02 & 3.47 & -2.03 \\
\hline$\Delta \mathrm{WCap} / \mathrm{SALE}$ & $0.0040^{* *}$ & 0.0037 & $0.0032^{*}$ & 0.0041 \\
\hline t-value & 2.05 & 1.10 & 1.65 & 1.26 \\
\hline$\Delta \mathrm{Capx} / \mathrm{SALE}$ & $0.0037^{*}$ & $0.0081^{* *}$ & 0.0003 & -0.0005 \\
\hline t-value & 1.89 & 2.51 & 0.16 & -0.17 \\
\hline$\Delta$ Lev/Equity & $-0.0110^{* * *}$ & $-0.0065^{* *}$ & $-0.0078^{* * *}$ & 0.0015 \\
\hline t-value & -5.63 & -2.00 & -4.04 & 0.48 \\
\hline$\Delta \mathrm{R} \& \mathrm{D} / \mathrm{SALE}$ & $0.0159^{* * *}$ & $0.0218^{* * *}$ & $0.0132^{* * *}$ & $0.0126^{* * *}$ \\
\hline t-value & $5 \cdot 57$ & 4.00 & 4.76 & 2.73 \\
\hline$\Delta$ Cash/Assets & $0.0042^{* *}$ & 0.0047 & 0.0027 & 0.0049 \\
\hline t-value & 2.19 & 1.43 & 1.42 & 1.52 \\
\hline Adj R² & 0.1229 & 0.0643 & 0.1126 & 0.0542 \\
\hline Obs & 5,272 & 4,854 & 5,279 & 4,934 \\
\hline Country Dummies & Yes & Yes & Yes & Yes \\
\hline
\end{tabular}

Notes. The $t$-value is $t$-statistic computed from the heteroscedasticity-consistent standard errors. ${ }^{*},{ }^{* *},{ }^{* * *}$ indicate significance at the $10 \%, 5 \%$, and $1 \%$ levels, respectively.

\section{Discussion-Implications and Limitations}

We link our results to extant literature and then discuss the implications and limitations of our findings. Our study investigated the relation among the economic recession in the U.S., the consequent changes in a firm's behaviors in emerging markets, and a firm's performance. While Hypothesis 1 (that a firm's behaviors and 
performance are impacted by external economic shocks) and Hypothesis 2 (that the changes in a firm's behaviors and performance vary with the level of organizational slack) were supported, what was more revealing was the specific nature of strategic behaviors.

\section{Links to Existing Literature}

Our results were in accordance with studies in strategic management that find that a firm's behaviors are directly linked to their firm's performance (Hayward \& Hambrick, 1997; Sanders \& Hambrick, 2007; To et al., 2018). Also, our results complemented extant literature, which found that the environmental context drove a firm's behaviors and performance, such as effects of external constraints (Hvide, 2002; Sanders \& Hambrick, 2007; Wiseman and Gomez-Mejia, 1998); intense competitive rivalry (e.g., Boyd \& De Nicolo, 2005); regulation, economic opportunities, and timing (Lehman \& Hahn, 2013; Zou et al., 2014), and whether the decision domain involved financial concerns (Blais \& Weber, 2006; Figner \& Murphy, 2011). Our study offered several theoretical advancements to the well-established "environmental determinism" theory in strategic management by providing empirical support for the effects of distant economic recessions across the globe.

Besides strengthening themes in existing research, our findings provided guidance for practical and differentiated responses for resource-constrained and resource-unconstrained firms when faced with external shocks resulting in a hostile external environment.

\section{Implications}

While we studied firms in emerging markets, we cannot claim that our results are generalizable across the globe. It can be expected that firms in different geographic realms or in different developing stages would exhibit different behaviors (Porter, 1990; Bakan \& Doğan, 2012). Hence, additional research should investigate the responses of firms in Europe, Latin America, and Africa or in different developing stages when faced with external shocks.

Our research provided unique perspectives and insights for managerial decision making in firms with and without resource constraints when facing economic recessions. Specifically, when faced with economic recession, all firms may respond with a similar set of changes in strategic variables. However, the impact of changes in strategic variables on a firm's performance could be different. In emerging markets where access to capital through financial institutions is limited, resource-constrained firms with minimum or no slack would have difficulty in making changes in strategic variables. In contrast, resource-unconstrained firms with slack would be able to make changes in strategic variables more easily.

The implications of our results for policy makers were also poignant. That R\&D expenditures are cut back in times of economic recessions is well known, but our results showed that resource-constrained firms' postcrisis performances were more adversely impacted from the increase in R\&D during the crisis period. This indicated that policy makers need to find a way to provide governmental support for R\&D (e.g., 150\% of R\&D expense as tax deductible), especially to resource-constrained firms in times of economic recessions.

\section{Limitations}

Although we exercised care in designing our study, it is not without limitations. First, while we primarily tested the impact of resource constraints on a firm's performance based on a resource-based view, recent studies (Bhandari et al., 2020; Weaven et al., 2021) suggest that while the available resources are important, other factors can significantly affect the firm's performance as well. For example, Bhandari et al. (2020) found that the attention of CEOs significantly affects the impact of exploring and exploiting resources on a firm's performance. This indicates that not only the available resources but also how CEOs allocate those recourses 
in various activities determine the firm's performance in subsequent periods. But the current study did not include the attention of CEOs in the empirical model and, therefore, is silent about its significance in explaining variation in a firm's performance. The second limitation relates to the measurement of the variables used: a firm's performance measure and how firms are categorized into constrained and unconstrained groups. While a firm's performance measure has been debated extensively among researchers, Alvarez et al. (2020) recently succinctly explained why a better measure of firm performance should be developed. They especially recognized the incompatibility of accounting-based performance measures, such as ROA/ROE, in management research. Because the current study used ROA/ROE as a firm's performance measure, the same criticism can be imposed. Another measurement issue pertains to resource constraint. Since the degree of resource constraint a firm faces is not directly observable, we used whether firms had a positive or negative ROA/ROE in the U.S. prerecession period to split the firms into constrained and unconstrained groups. However, it is possible that different measures of resource constraints may be more suitable for different countries. Third, as noted, our results may not be consistent in the other regions or in the countries at different stages of development. Therefore, additional research is needed to investigate if these results hold for firms in Europe, Latin America, and Africa or in developed countries. Fourth, the independent variables we used in this study were based on financial statements. However, there are more strategy variables not covered in financial statements, such as organizational structure, marketing campaigns, product mix, etc. Future studies filling the gap in these limitations may yield more generalizable results.

\section{Conclusion}

Faced with external shocks, such as significant setbacks in the economic system, firms in different regions or in different stages of development are forced to react by changing their stance in the set of strategies, inevitably affecting the subsequent period of a firm's performance. Perhaps more importantly, resourceconstrained firms may not have the resources to make changes in strategy variables compared with those that are resource unconstrained. This means that for resource-constrained firms, there may not be many strategy variables affecting a firm's performance in the years after the crisis due to the low variation in strategy variables. While there are many strategy variables that can be used to explain a firm's performance, the strategy variables captured in the financial statements are the easiest ones to get.

Our study investigated whether firms from emerging markets, when faced with the economic shock generated by the economic recession of 2007-2008, changed their strategy variables and experienced better firm performance due to the changes in the postcrisis period. We found that while increase in sales, equity capital, $\mathrm{R} \& \mathrm{D}$, and cash tended to generate better firm performance in the postcrisis period, increase in debt tended to generate worse firm performance in the postcrisis period. Additional results showed that the change in significant variables' impact on the subsequent period of a firm's performance is much stronger for resourceunconstrained firms. We interpreted this latter result as indicating that resource-unconstrained firms would have more slack resources necessary to make changes in strategy variables even in the crisis period and, hence, the impact of change in strategy variables on a firm's performance in the postcrisis period would be more for them. 


\section{References}

Abel, A. B. (2018). Optimal debt and profitability in the tradeoff theory. The Journal of Finance, 73(1), 95143. https://doi.org/10.1111/jofi.12590

Aktas, N., Croci, E., and Petmezas, D. (2015). Is working capital management value-enhancing? Evidence from firm performance and investments. Journal of Corporate Finance, 30(1), 98-113. https://doi.org/10.1016/j.jcorpfin.2014.12.008

Almazari, A. A. (2012). Financial performance analysis of the Jordanian Arab Bank by using the DuPont system of financial analysis. International Journal of Economics and Finance, 4(4), 86-97. https://doi.org/10.5539/ijef.v4n4p86

Alvarez, S. A., Zander, U., Barney, J. B., \& Afuah, A. (2020). Developing a theory of the firm for the 21st century. Academy of Management Review, 45(4), 711-716. https://doi.org/10.5465/amr.2020.0372

Baden-Fuller, C., \& Haefliger, S. (2013). Business models and technological innovation. Long Range Planning, 46(6), 419-426. https://doi.org/10.1016/j.lrp.2013.08.023

Bakan, I., \& Doğan, İ. F. (2012). Competitiveness of the industries based on the Porter's diamond model: An empirical study. International Journal of Research and Reviews in Applied Sciences, 11(3), 441-455.

Bansal, P. (2003). From issues to actions: The importance of individual concerns and organizational values in responding to natural environmental issues. Organization Science, 14(5), 510-527. https://doi.org/10.1287/orsc.14.5.510.16765

Beck, T., \& Demirgüç-Kunt, A. (2008). Access to finance: An unfinished agenda. The World Bank Economic Review, 22(3), 383-396. https://doi.org/10.1093/wber/lhno21

Bhandari, K. R., Rana, S., Paul, J., \& Salo, J. (2020). Relative exploration and firm performance: Why resource-theory alone is not sufficient? Journal of Business Research, 118, 363-377. https://doi.org/10.1016/j.jbusres.2020.07.001

Blais, A. R., \& Weber, E. U. (2006). A domain-specific risk taking (DOSPERT) scale for adult populations. Judgment and Decision Making, 1(1), 33-47.

Bliss, B. A., Cheng, Y., \& Denis, D. J. (2015). Corporate payout, cash retention, and the supply of credit: Evidence from the 2008-2009 credit crisis. Journal of Financial Economics, 115(3), 521-540. https://doi.org/10.1016/j.jfineco.2014.10.013

Bogers, M., Hadar, R., \& Bilberg, A. (2016). Additive manufacturing for consumer-centric business models: Implications for supply chains in consumer goods manufacturing. Technological Forecasting and Social Change, 102(3), 225-239. https://doi.org/10.1016/j.techfore.2015.07.024

Boyd, J. H., \& De Nicolo, G. (2005). The theory of bank risk taking and competition revisited. The Journal of Finance, 6o(3), 1329-1343. https://doi.org/10.1111/j.1540-6261.2005.00763.x

Caggese, A., Cunat, V., \& Metzger, D. (2018). Firing the wrong workers: Financial constraints and labor allocation. Journal of Financial Economics. 133(3), 589-607. https://doi.org/10.1016/j.jfineco.2017.10.008

Campello, M., Graham, J. R., \& Harvey, C. R. (2010). The real effects of financial constraints: Evidence from a financial crisis. Journal of Financial Economics, 97(3), 470-487. https://doi.org/10.1016/j.jfineco.2010.02.009

Carpenter, M. A. (2002). The implications of strategy and social context for the relationship between top management team heterogeneity and firm performance. Strategic Management Journal, 23(3), 275-284. 
Chang, D. S., Kuo, P. W., \& Tsao, S. M. (2012). Measuring the financing and business performance of the information technology industry. African Journal of Business Management, 6(3), 1164-1179.

Chang, Y., Benson, K., \& Faff, R. (2017). Are excess cash holdings more valuable to firms in times of crisis? Financial constraints and governance matters. Pacific-Basin Finance Journal, 45, 157-173. https://doi.org/10.1016/j.pacfin.2016.05.007

Chinta, R., \& Culpan, R. (2014). The role of open innovation in business-university R\&D collaborations. In R. Culpan (Ed.). Open Innovation through Strategic Alliances, pp. 145-165. Palgrave MacMillan. https://doi.org/10.1057/9781137394507_8

Cole, C., Yan, Y., \& Hemley, D. (2015). Does capital structure impact firm performance: An empirical study of three US sectors? Journal of Accounting and Finance, 15(6), 57-69.

Cooper, M. J., Gulen, H., \& Schill, M. J. (2008). Asset growth and the cross-section of stock returns. The Journal of Finance, 63(4), 1609-1651. https://doi.org/10.1111/j.1540-6261.2008.01370.x

Cozzolino, A., \& Rothaermel, F. T. (2018). Discontinuities, competition, and cooperation: Coopetitive dynamics between incumbents and entrants. Strategic Management Journal, 39(12), 3053-3085. https://doi.org/10.1002/smj.2776

Cusumano, M. A. (2010). Staying power: Six enduring principles for managing strategy and innovation in an uncertain world (lessons from Microsoft, Apple, Intel, Google, Toyota and more). Oxford University Press.

Dalton, D. R., Daily, C. M., Certo, S. T., \& Roengpitya, R. (2003). Meta-analyses of financial performance and equity: Fusion or confusion? Academy of Management Journal, 46(1), 13-26. https://doi.org/10.2307/30040673

Deloof, M. (2003). Does working capital management affect profitability of Belgian firms? Journal of Business Finance \& Accounting, 3o(3-4), 573-588. https://doi.org/10.1111/1468-5957.00008

Denicolai, S., Ramirez, M., \& Tidd, J. (2014). Creating and capturing value from external knowledge: The moderating role of knowledge intensity. R\&D Management, 44(3), 248-264. https://doi.org/10.1111/radm.12065

Dess, G. G., McNamara, G., Eisner, A. B., \& Lee, S. H. (2019). Strategic Management: Text and Cases (9th ed.). McGraw Hill Education.

Dewatripont, M., \& Tirole, J. (1994). A theory of debt and equity: Diversity of securities and managershareholder congruence. The Quarterly Journal of Economics, 109(4), 1027-1054. https://doi.org/10.2307/2118355

Ding, S., Guariglia, A., \& Knight, J. (2013). Investment and financing constraints in China: Does working capital management make a difference? Journal of Banking \& Finance, 37(5), 1490-1507. https://doi.org/10.1016/j.jbankfin.2012.03.025

Dittmar, A., Mahrt-Smith, J., \& Servaes, H. (2003). International corporate governance and corporate cash holdings. Journal of Financial and Quantitative Analysis, 38(1), 111-133. https://doi.org/10.2307/4126766

Domowitz, I., Hubbard, R. G., \& Peterson, B. C. (1988). Market structure and cyclical fluctuations in U.S. manufacturing. The Review of Economics and Statistics, 7o(1), 55-66. https://doi.org/10.2307/1928150

Easterby-Smith, M., Lyles, M. A., \& Peteraf, M. A. (2009). Dynamic capabilities: Current debates and future directions. British Journal of Management, 2O, S1-S8. https://doi.org/10.1111/j.14678551.2008.00609.x 
Eisenmann, T. R. (2006). Internet companies' growth strategies: Determinants of investment intensity and long-term performance. Strategic Management Journal, 27(12), 1183-1204. https://doi.org/10.1002/smj.567

Enqvist, J., Graham, M., \& Nikkinen, J. (2014). The impact of working capital management on firm profitability in different business cycles: Evidence from Finland. Research in International Business and Finance, 32, 36-49. https://doi.org/10.1016/j.ribaf.2014.03.005

Evans, D. S. (1987). The relationship between firm growth, size, and age: Estimates for 100 manufacturing industries. The Journal of Industrial Economics, 35(4), 567-581. https://doi.org/10.2307/2098588

Fama, E. F., \& French, K. R. (2006). Profitability, investment and average returns. Journal of Financial Economics, 82(3), 491-518. https://doi.org/10.1016/j.jfinec0.2005.09.009

Fazzari, S. M., Hubbard, R. G., \& Petersen, B. C. (1988). Financial constraints and corporate investment. Brookings Paper on Economic Activity, 1, 141-206. https://doi.org/10.2307/2534426

Figner, B., \& Murphy, R. O. (2011). Using skin conductance in judgment and decision making research. In M. Schulte-Mecklenback, A. Kuehberger, \& R. Ranyard (Eds.). A handbook of process tracing methods for decision research. pp. 163-184. Psychology Press.

Frazzini, A., \& Pedersen, L. H. (2014). Betting against beta. Journal of Financial Economics, 111(1), 1-25. https://doi.org/10.1016/j.jfineco.2013.10.005

Gabisch, G., \& Lorenz, H. (1987). Business cycle theory: A survey of method and concepts. Springer-Verlag.

George, G. (2005). Slack resources and the performance of privately held firms. Academy of Management Journal, 48(4), 661-676. https://doi.org/10.5465/amj.2005.17843944

Geroski, P. A., \& Gregg, P. (1997). Coping with recession: UK company performance in adversity (Vol. 38). Cambridge University Press.

Gill, A., Biger, N., \& Mathur, N. (2010). The relationship between working capital management and profitability: Evidence from the United States. Business and Economics Journal, 1O(1), 1-9.

González, F. (2016). Creditor rights, bank competition, and corporate investment during the global financial crisis. Journal of Corporate Finance, 37, 249-270. https://doi.org/10.1016/j.jcorpfin.2016.01.001

González-Pernía, J. L., Guerrero, M., Jung, A., \& Peña-Legazkue, I. (2018). Economic recession shake-out and entrepreneurship: Evidence from Spain. BRQ Business Research Quarterly, 21(3), 153-167. https://doi.org/10.1016/j.brq.2018.06.001

Gottfredson, M., \& Schaubert, S. (2008). The breakthrough imperative, how the best managers get outstanding results. HarperCollins.

Grabowski, H., Vernon, J., \& DiMasi, J. A. (2002). Returns on research and development for 1990 os new drug introductions. PharmacoEconomics, 2O(3), 11-29. https://doi.org/10.2165/00019053-20022000300002

Hahn, T., Chinta, R., \& Palkar, D. (2017). Strategy behaviors of firms in times of external shocks and their impact on operating performance-an event study. SAM Advanced Management Journal, 82(4), 61-71.

Hauser, J., Tellis, G. J., \& Griffin, A. (2006). Research on innovation: A review and agenda for Marketing Science. Marketing Science, 25(6), 687-717. https://doi.org/10.1287/mksc.1050.0144

Hayward, M. L. A., \& Hambrick, D. C. (1997). Explaining the premiums paid for large acquisitions: Evidence of CEO hubris. Administrative Science Quarterly, 42(1), 103-127. https://doi.org/10.2307/2393810

Hess, E. D., \& Kazanjian, R. K. (Eds.) (2006). The search for organic growth. Cambridge University Press.

Hong, H., Lim, T., \& Stein, J. C. (2000). Bad news travels slowly: Size, analyst coverage, and the profitability 
of momentum strategies. The Journal of Finance, 55(1), 265-295. https://doi.org/10.1111/o0221082.00206

House, W. C., Parks, D. M., \& Lindstrom, G. L. (1994). Relationships between R\&D and profitability: An exploratory comparison of two business simulations with two real-world technology intensive industries. Developments in Business Simulation and Experiential Learning, 21, 75-78.

Hvide, H. K. (2002). Tournament rewards and risk taking. Journal of Labor Economics, 20(4), 877-898. https://doi.org/10.1086/342041

İmrohoroğlu, A., \& Tüzel, S. (2014). Firm-level productivity, risk, and return. Management Science, 6o(8), 2073-2090. https://doi.org/10.1287/mnsc.2013.1852

Joliet, R., \& Muller, A. (2013). Capital structure effects of international expansion. Journal of Multinational Financial Management, 23(5), 375-393. https://doi.org/10.1016/j.mulfin.2013.08.002

Juan García-Teruel, P., \& Martinez-Solano, P. (2007). Effects of working capital management on SME profitability. International Journal of Managerial Finance, 3(2), 164-177. https://doi.org/10.1108/17439130710738718

Keller, R. T. (1994). Technology-information processing fit and the performance of R\&D project groups: A test of contingency theory. Academy of Management Journal, 37(1), 167-179. https://doi.org/10.5465/256775

Kieschnick, R., Laplante, M., \& Moussawi, R. (2013). Working capital management and shareholders' wealth. Review of Finance, 17(5), 1827-1852. https://doi.org/10.1093/rof/rfso43

Kim, C.-S., Mauer, D. C., \& Sherman, A. E. (1998). The determinants of corporate liquidity: Theory and evidence. Journal of Financial and Quantitative Analysis, 33(3), 335-359. https://doi.org/10.2307/2331099

Lado, A. A., Boyd, N. G., \& Wright, P. (1992). A competency-based model of sustainable competitive advantage: Toward a conceptual integration. Journal of Management, 18(1), 77-91. https://doi.org/10.1177/014920639201800106

Lamont, O. (1997). Cash flow and investment: Evidence from internal capital markets. The Journal of Finance, 52(1), 83-109. https://doi.org/10.1111/j.1540-6261.1997.tbo3809.x

Latham, S. F., \& Braun, M. R. (2008). The performance implications of financial slack during economic recession and recovery: observations from the software industry (2001-2003). Journal of Managerial Issues, 2O(1), 30-50.

Lawrence, P. R., \& Lorsch, J. W. (1967). Differentiation and integration in complex organizations. Administrative Science Quarterly, 12(1), 1-47. https://doi.org/10.2307/2391211

Le Breton-Miller, I., \& Miller, D. (2015). The paradox of resource vulnerability: Considerations for organizational curatorship. Strategic Management Journal, 36(3), 397-415. https://doi.org/10.1002/smj.2220

Lehman, D. W., \& Hahn, J. (2013). Momentum and organizational risk taking: Evidence from the National Football League. Management Science, 59(4), 852-868. https://doi.org/10.1287/mnsc.1120.1574

Lins, K. V., Volpin, P., \& Wagner, H. F. (2013). Does family control matter? International evidence from the 2008-2009 financial crisis. Review of Financial Studies, 26(10), 2583-2619. https://doi.org/10.1093/rfs/hhto44

Mandacı, P., \& Gumus, G. (2010). Ownership concentration, managerial ownership and firm performance: Evidence from Turkey. South East European Journal of Economics and Business, 5(1), 57-66. https://doi.org/10.2478/v10033-010-0005-4

Margaritis, D., \& Psillaki, M. (2010). Capital structure, equity ownership and firm performance. Journal of 
Banking \& Finance, 34(3), 621-632. https://doi.org/10.1016/j.jbankfin.2009.08.023

Mikkelson, W. H., \& Partch, M. M. (2003). Do persistent large cash reserves hinder performance? Journal of Financial and Quantitative Analysis, 38(2), 275-294. https://doi.org/10.2307/4126751

Mizen, P., \& Tsoukas, S. (2012). The response of the external finance premium in Asian corporate bond markets to financial characteristics, financial constraints and two financial crises. Journal of Banking and Finance, 36(11), 3048-3059. https://doi.org/10.1016/j.jbankfin.2012.07.005

Morbey, G. K., \& Reithner, R. M. (1990). How R\&D affects sales growth, productivity and profitability. Research-Technology Management, 33(3), 11-14. https://doi.org/10.1080/08956308.1990.11670656

Nakao, T. (1993). Market share, advertising, R\&D, and profitability: An empirical analysis of leading industrial firms in Japan. Review of Industrial Organization, 8(3), 315-328. https://doi.org/10.1007/bfo1024237

Opler, T., Pinkowitz, L., Stulz, R., \& Williamson, R. (1999). The determinants and implications of corporate cash holdings. Journal of Financial Economics, 52(1), 3-46. https://doi.org/10.3386/w6234

O’Reilly, C. A., III, \& Pfeffer, J. (2000). Hidden value. How great companies achieve extraordinary results with ordinary people. Harvard Business School Press, Boston

Palkar, D. D. (2017). Cash flow volatility-return relation and financial constraints: International evidence. Managerial Finance, 43(3), 354-378. https://doi.org/10.1108/mf-07-2016-0214

Patel, P. C., \& Cooper, D. (2014). The harder they fall, the faster they rise: Approach and avoidance focus in narcissistic CEOs. Strategic Management Journal, 35(10), 1528-1540. https://doi.org/10.1002/smj.2162

Penman, S. H., Richardson, S. A., \& Tuna, İ. (2007). The book-to-price effect in stock returns: Accounting for leverage. Journal of Accounting Research, 45(2), 427-467. https://doi.org/10.1111/j.1475679x.2007.00240.x

Peteraf, M. A., \& Barney, J. B. (2003). Unraveling the resource-based tangle. Managerial and Decision Economics, 24(4), 309-323. https://doi.org/10.1002/mde.1126

Pfeffer, J., \& Salancik, G. (1978). The external control of organizations. Harper and Row.

Porter, M. E. (1990). The Competitive Advantage of Nations. Free Press, Macmillan.

Porter, M. E. (1981). The contributions of industrial organization to strategic management. Academy of Management Review, 6(4), 609-620. https://doi.org/10.5465/amr.1981.4285706

Rusu, V. D., \& Roman, A. (2017). Entrepreneurial activity in the EU: An empirical evaluation of its determinants. Sustainability, 9(10), 1679. https://doi.org/10.3390/su9101679

Sanders, W. G., \& Hambrick, D. C. (2007). Swinging for the fences: The effects of CEO stock options on company risk taking and performance. Academy of Management Journal, 5O(5), 1055-1078. https://doi.org/10.5465/amj.2007.27156438

Severn, A. K., \& Laurence, M. M. (1974). Direct investment, research intensity, and profitability. Journal of Financial and Quantitative Analysis, 9(2), 181-190. https://doi.org/10.2307/2330094

Simons, T. (2008). The integrity dividend, leading by the power of your word. Jossey-Bass.

Singh, J. V. (1986). Performance, slack, and risk taking in organizational decision making. Academy of Management Journal, 29(3), 562-585. https://doi.org/10.5465/256224

Spear, S. J. (2009). Chasing the rabbit, how market leaders outdistance the competition and how great companies can catch up and win. McGraw-Hill.

Tappin, S., \& Cave, A. (2008). The secrets of CEOs. Nicholas Brealey Publishing. 
Teece, D. J. (2007). Explicating dynamic capabilities: The nature and microfoundations of (sustainable) enterprise performance. Strategic Management Journal, 28(13), 1319-1350. https://doi.org/10.1002/smj.640

Thoenig, J.-C., \& Waldman, C. (2007). The marking enterprise: Business success and societal embedding. INSEAD Business Press/Palgrave MacMillan.

Thompson, J. D. (2017). Organizations in action: Social science bases of administrative theory. Routledge.

To, C., Kilduff, G. J., Ordoñez, L., \& Schweitzer, M. E. (2018). Going for it on fourth down: Rivalry increases risk taking, physiological arousal, and promotion focus. Academy of Management Journal, 61(4), 1281-1306. https://doi.org/10.5465/amj.2016.0850

Uyar, A. (2009). The relationship of cash conversion cycle with firm size and profitability: An empirical investigation in Turkey. International Research Journal of Finance and Economics, 24(2), 186-193.

Vanacker, T., Collewaert, V., \& Zahra, S. A. (2017). Slack resources, firm performance, and the institutional context: Evidence from privately held European firms. Strategic Management Journal, 38(6), 13051326. https://doi.org/10.1002/smj.2583

Venkatraman, N. (1989). The concept of fit in strategy research: Toward verbal and statistical correspondence. Academy of Management Review, 14(3), 423-444. https://doi.org/10.5465/amr.1989.4279078

Weaven, S., Quach, S., Thaichon, P., Frazer, L., Billot, K., \& Grace, D. (2021). Surviving an economic downturn: Dynamic capabilities of SMEs. Journal of Business Research, 128, 109-123. https://doi.org/10.1016/j.jbusres.2021.02.009

Wernerfelt, B. (1984). A resource-based view of the firm. Strategic Management Journal, 5(2), 171-180.

Wernerfelt, B. (1995). The resource-based view of the firm: Ten years after. Strategic Management Journal, 16(3), 171-174. https://doi.org/10.1002/smj.4250160303

White, H. (1980). A heteroskedasticity-consistent covariance matrix estimator and a direct test for heteroscedasticity. Econometrica 48(4), 817-838. https://doi.org/10.2307/1912934

Wintoki, M. B., Linck, J. S., \& Netter, J. M. (2012). Endogeneity and the dynamics of internal corporate governance. Journal of Financial Economics, 105(3), 581-606. https://doi.org/10.1016/j.jfineco.2012.03.005

Wiseman, R. M., \& Gomez-Mejia, L. R. (1998). A behavioral agency model of managerial risk taking. Academy of Management Review, 23(1), 133-153. https://doi.org/10.5465/amr.1998.192967

Wu, L.-Y. (2007). Entrepreneurial resources, dynamic capabilities and start-up performance of Taiwan's high-tech firms. Journal of Business Research, 6o(5), 549-555. https://doi.org/10.1016/j.jbusres.2007.01.007

Zarnowitz, V. (1985). Recent work on business cycles in historical perspective: A review of theories and evidence. Journal of Economic Literature, 23, 523-580. https://doi.org/10.3386/w1503

Zou, X., Scholer, A. A., \& Higgins, E. T. (2014). In pursuit of progress: Promotion motivation and risk preference in the domain of gains. Journal of Personality and Social Psychology, 106, 183-201. https://doi.org/10.1037/aoo35391

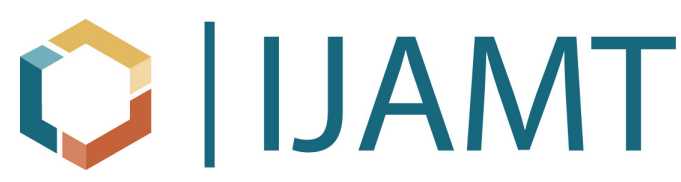

The International Journal of Applied Management and Technology (IJAMT), sponsored by Walden University's College of Management and Technology, is a peer-reviewed, online journal that addresses contemporary national and international issues related to management and technology. 